SOT T

www.toxsci.oxfordjournals.org

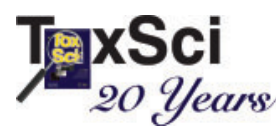

doi: $10.1093 /$ toxsci/kfy006

Advance Access Publication Date: January 8, 2018

Research Article

\title{
N-Acetyl-2-Aminofluorene (AAF) Processing in Adult Rat Hepatocytes in Primary Culture Occurs by High-Affinity Low-Velocity and Low-Affinity High-Velocity AAF Metabolite-Forming Systems
}

\author{
Katherine S. Koch, ${ }^{*, 1}$ Tom Moran, ${ }^{*, 2}$ W. Thomas Shier, ${ }^{\dagger}$ and Hyam L. Leffert ${ }^{*, 1}$ \\ *Department of Pharmacology, School of Medicine, University of California, San Diego, La Jolla, California \\ 92093; and ${ }^{\dagger}$ Department of Medicinal Chemistry, College of Pharmacy, University of Minnesota-Twin Cities, \\ Minneapolis, Minnesota 55455
}

${ }^{1}$ To whom correspondence should be addressed: Department of Pharmacology, UCSD School of Medicine, 9500 Gilman Drive, La Jolla, CA $92093-0636$. Tel: 01-858-534-2354; Fax: 01-858-822-4184; E-mail: kskoch@ucsd.edu or hleffert@ucsd.edu.

${ }^{2}$ Deceased

\begin{abstract}
$\mathrm{N}$-acetyl-2-aminofluorene (AAF) is a procarcinogen used widely in physiological investigations of chemical hepatocarcinogenesis. Its metabolic pathways have been described extensively, yet little is known about its biochemical processing, growth cycle expression, and pharmacological properties inside living hepatocytes-the principal cellular targets of this hepatocarcinogen. In this report, primary monolayer adult rat hepatocyte cultures and high specific-activity [ring $\left.\mathrm{G}-{ }^{3} \mathrm{H}\right]-\mathrm{N}$-acetyl-2aminofluorene were used to extend previous observations of metabolic activation of AAF by highly differentiated, proliferation-competent hepatocytes in long-term cultures. AAF metabolism proceeded by zero-order kinetics. Hepatocytes processed significant amounts of procarcinogen $\left(\approx 12 \mu \mathrm{g} \mathrm{AAF} / 10^{6}\right.$ cells/day). Five ring-hydroxylated and one deacetylated species of AAF were secreted into the culture media. Extracellular metabolite levels varied during the growth cycle (days 0-13), but their rank quantitative order was time invariant: 5-OH-AAF $>7-\mathrm{OH}-\mathrm{AAF}>3-\mathrm{OH}-\mathrm{AAF}>\mathrm{N}-\mathrm{OH}-\mathrm{AAF}>$ aminofluorene (AF) > 1-OH-AAF. Lineweaver-Burk analyses revealed two principal classes of metabolism: System I (high-affinity and lowvelocity), $K_{\mathrm{m} \text { [APPARENT] }}=1.64 \times 10^{-7} \mathrm{M}$ and $\mathrm{V}_{\mathrm{MAX} \text { [APPARENT] }}=0.1 \mathrm{nmol} / 10^{6}$ cells $/$ day and System II (low-affinity and highvelocity), $K_{\mathrm{m} \text { [APPARENT] }}=3.25 \times 10^{-5} \mathrm{M}$ and $\mathrm{V}_{\text {MAX[APPARENT] }}=1000 \mathrm{nmol} / 10^{6}$ cells $/$ day. A third system of metabolism of AAF to $\mathrm{AF}$, with $\mathrm{K}_{\mathrm{m} \text { [APPARENT] }}$ and $\mathrm{V}_{\text {MAX[APPARENT] }}$ constants of $9.6 \times 10^{-5} \mathrm{M}$ and $4.7 \mathrm{nmol} / 10^{6}$ cells/day, was also observed. Evidence provided in this report and its companion paper suggests selective roles and intracellular locations for System I- and System II-mediated AAF metabolite formation during hepatocarcinogenesis, although some of the molecules and mechanisms responsible for multi-system processing remain to be fully defined.
\end{abstract}

Key words: hepatocarcinogenesis; N-acetyl-2-aminofluorene; procarcinogen processing; primary hepatocytes.

Hepatocellular carcinoma (HCC) is the third leading cause of cancer-related deaths worldwide ( $>600000$ deaths per year) and the seventh most common cancer (American Cancer Society, 2018; Koch and Leffert, 2015; Mishra et al., 2009; Yang and Roberts, 2010). A wealth of information about the phenomenon of chemical hepatocarcinogenesis has come from investigations of the induction of adult rat HCC (Becker, 1975; Miller, 1978; Weinstein, 1978). Aromatic amines like N-acetyl-2-aminofluorene (AAF) are principal inducers used in these investigations (Kriek, 1974; Weisburger and Weisburger, 1973). Hepatocarcinogenic doses of AAF do not cause tumors when applied topically (Miller et al., 1961). Instead, AAF must first undergo a series of 
intrahepatic chemical changes. Following rate-limiting $\mathrm{N}$-hydroxylation, sulfate esterification occurs, followed by conversion to more active carcinogenic electrophiles which can form DNA adducts such as dG-C8-AAF and dG-C8-AF (Kriek, 1992; Luo et al., 2000), which ultimately result in HCCs (Bartsch et al., 1972; Cramer et al., 1960; Gutmann et al., 1967; Irving, 1962; Kiese et al., 1966; Lotlikar and Luha, 1971; Miller et al., 1960; Morris et al., 1956; Weisburger et al., 1964). The biochemical transformations are performed by hepatocellular enzymes, which are present in the liver at levels higher than in other tissues (DeBaun et al., 1970; Leffert et al., 1977; Santostefano et al., 1999; Schrenk et al., 1994), particularly by Cyp1A2, which converts AAF to N-OH-AAF. This explains the selectivity-and the utility - of AAF in model studies of rat hepatocarcinogenesis. Other sites, including the bladder, mammary glands and pancreas, are at risk of AAF-induced malignancy, although less frequently (Wilson et al., 1941).

Although much is known about the metabolic pathways of AAF, little is known about the cell biology and pharmacology of AAF processing inside living hepatocytes, the major intrahepatic cellular target of this procarcinogen (Koch and Leffert, 2015). A series of experiments were conducted using a wellcharacterized primary adult rat hepatocyte culture system to quantify the early biochemical processing and biological effects of AAF, and to elucidate the intracellular properties of processing in relation to hepatocyte DNA synthesis and cell division. These investigations are described in this and the subsequent report (Koch et al., 2018).

This report focuses on AAF uptake and metabolism; the subsequent report (Koch et al., 2018) focuses on macromolecule binding properties of AAF in relation to hepatocyte proliferation. A third report (Koch et al., in preparation) will describe similar measurements of AAF properties in cultured hepatocytes obtained from livers of adult rats fed a cyclic carcinogenic diet of AAF (Teebor and Becker, 1971).

The results of these studies reveal previously unrecognized aspects of AAF processing, namely the presence of two principal classes of metabolizing systems (high $K_{\text {m[APPARENT], low }}$ $V_{\text {MAX[APPARENT] }}$ and low $K_{\text {m[APPARENT] }}$, high $V_{\text {MAX[APPARENT] }}$ ) and two principal classes of binding sites (high $K_{\mathrm{D} \text { [APPARENT] }}$, low $B_{\text {MAX[APPARENT] }}$ and low $K_{\text {D[APPARENT] }}$, high $B_{\text {MAX[APPARENT] }}$ ). These results have important implications for the mechanisms of AAF processing in relation to hepatocarcinogenesis. Preliminary findings were described elsewhere (Koch and Leffert, 1980; Leffert et al., 1977, 1983).

\section{MATERIALS AND METHODS}

Primary hepatocyte culture. Hepatocytes from adult male Fischer 344 rats (180-200 g) were isolated by intraportal perfusion with a collagenase cocktail as described previously (Leffert et al., 1977, 1979). Institutional and Animal Care Use Committee regulations at UCSD and NIH guidelines for the care and use of animals were followed. Unless noted, $1 \times 10^{6}$ viable cells $\left(N_{0}\right)$ were plated into Falcon plastic tissue culture dishes $(3.5 \mathrm{~cm}$ diameter) containing $2 \mathrm{ml}$ arginine-free Dulbecco and Vogt's Modified Eagle's Medium. The medium was supplemented with heat-inactivated $15 \%(\mathrm{v} / \mathrm{v})$ dialyzed fetal bovine serum, $0.2 \mathrm{mM}$ L-ornithine, and $10 \mu \mathrm{g}$ each of insulin, inosine, and hydrocortisone-succinate/ml. Attached cells (viability $>95 \%$ ) were recovered by trypsinization, and cell numbers were determined using a Coulter Counter (Leffert et al., 1979). The reagents and chemicals required for cell culture have been described elsewhere (Leffert et al., 1979).
Unless noted, all measurements were made using 3 dishes per point with errors $\pm 10 \%$.

Sources and synthesis of radiolabeled AAF. N-acetyl-9- $\left[{ }^{14} \mathrm{C}\right]-2-$ aminofluorene $\left(\left[{ }^{14} \mathrm{C}\right]-\mathrm{AAF}\right)$ was obtained from New England Nuclear (NEN; Boston, MA [Leffert et al., 1977]). Its purity and specific activity were $>98 \%$ and $100 \mathrm{dpm} \mathrm{pmol}^{-1}$, respectively.

[Ring G- $\left.{ }^{3} \mathrm{H}\right]-\mathrm{N}$-acetyl-2-aminofluorene $\left.\left({ }^{3} \mathrm{H}\right]-\mathrm{AAF}\right)$ was synthesized from 2-AF (AF or 2-aminofluorene, Aldrich Chemical Co., Milwaukee, Wisconsin). The precursor was labeled with tritium by catalytic exchange at NEN. Tritiated precursor $(150 \mathrm{mg})$ was dissolved in $0.3 \mathrm{ml}$ of glacial acetic acid and mixed with $50 \mathrm{mg}$ of platinum catalyst and $25 \mathrm{Ci}$ of tritiated $\mathrm{H}_{2} \mathrm{O}$. The reaction mixture was stirred overnight at $80^{\circ} \mathrm{C}$ and the labile tritium removed by evaporation in vacuo. The residue was suspended in $\mathrm{MeOH}$, filtered to remove the catalyst and subjected to repeated cycles of dissolution in $\mathrm{MeOH}$ and evaporation in vacuo. The product of this treatment contained substantial radioactivity which comigrated with AAF (Aldrich Chemical) as assessed by thin layer chromatography (TLC) on silica gel GF plates (Analtech, Inc., Newark, Delaware) in benzene:acetone [8:2]. The product was saponified by heating an aliquot representing $3 \mathrm{mg}$ starting material for $4 \mathrm{~h}$ at $90^{\circ} \mathrm{C}$ in a mixture of $4 \mathrm{ml} \mathrm{EtOH}$ and $8 \mathrm{ml}$ of $50 \%$ aqueous $\mathrm{KOH}$. The mixture was cooled and extracted with $40 \mathrm{ml}$ of ether. The ether extract was washed with $\mathrm{H}_{2} \mathrm{O}$ and dried over anhydrous $\mathrm{MgSO}_{4}$. The ether was evaporated and $\left[\mathrm{G}^{3} \mathrm{H}\right]$-2-aminofluorene purified from the residue by preparative TLC carried out as described earlier, and using $\mathrm{MeOH}$ to elute the material migrating at the same rate as an authentic AAF sample on a parallel track. The $\mathrm{MeOH}$ extract was evaporated in vacuo and the residue acetylated by dissolving it in $1 \mathrm{ml}$ benzene containing $50 \mu \mathrm{l}$ of acetic anhydride and allowing it to stand overnight at room temperature. The mixture was evaporated in vacuo and $\left[{ }^{3} \mathrm{H}\right]-\mathrm{AAF}$ purified from the residue by preparative TLC. The product of this procedure was crystallized from aqueous EtOH. The crystalline material was dissolved in EtOH and stored at $-20^{\circ} \mathrm{C}$. The specific activity was determined by the optical density at $285 \mathrm{~nm}$ compared with a known concentration of an authentic AAF sample. Radioactivity was determined by scintillation counting an aliquot of a dilution in Liquifluor-toluene (NEN). The specific activity of the final $\left[{ }^{3} \mathrm{H}\right]-$ AAF product was $4000 \mathrm{dpm} \mathrm{pmol}{ }^{-1}$.

Isolation and quantification of radiolabeled AAF metabolites. Freshly harvested cell-free culture fluids $(2 \mathrm{ml} /$ dish) were incubated with $\beta$-glucuronidase and $\alpha$-amylase, and extracted with acidified organic solvents as previously described (Leffert et al., 1977). Radiolabeled products in the processed extracts $(\approx 65 \%$ of the counts) were assayed in parallel by TLC in chloroform:methanol [97:3] and benzene:acetone [4:1], as described previously (Leffert et al., 1977). The two TLC systems were necessary to separate 1- and 3-position ring-hydroxylated AAF metabolites from parental AAF. Radioactivity in the samples was quantified by scintillation counting as described previously (Leffert et al., 1977). The yields of extracted metabolites that were recovered on TLC plates under both conditions were $>95 \%$. Authentic AAF and AAF-metabolite standards were used for comparison to identify and quantify the comigrating metabolites in parallel TLC tracks (Leffert et al., 1977).

Quantification of cellular levels of intracellular free AAF and of covalently bound AAF metabolites. At various times postplating, $\left[{ }^{3} \mathrm{H}\right]-$ $\mathrm{AAF}$ or $\left[{ }^{14} \mathrm{C}\right]-\mathrm{AAF}$ was added to the cultures in $\mathrm{EtOH}$ vehicle for different intervals of time, as indicated in the Results and Figure 
Legends. Serial dilutions were made over broad concentration ranges, so that the specific activities of radiolabeled AAF were identical at each AAF concentration. At various times, thereafter, the monolayers were washed $3 \times$ with $2 \mathrm{ml}$ of ice-cold $\mathrm{Ca}^{2+}$ and $\mathrm{Mg}^{2+}$-supplemented Tris-HCl buffer, pH.7.4, and extracted with $2 \mathrm{ml}$ of $5 \%$ trichloroacetic acid (TCA) overnight in darkness at $4^{\circ} \mathrm{C}$. The TCA-soluble extracts were used to quantify the cellular concentrations of free intracellular AAF $\left([\mathrm{AAF}]_{\mathrm{i}}\right)$. The remaining extracts were solubilized (Kruijer et al., 1986), heated at $100^{\circ} \mathrm{C}$ for $2 \mathrm{~min}$, and brought to room temperature. Covalently bound radiolabeled material in the extracts was precipitated with ice-cold 10\% TCA onto Whatman GF/C filters. The filters were washed with ice-cold EtOH, air dried, and subjected to scintillation counting to errors of $\pm 1 \%$ (Leffert et al., 1977). Counting efficiencies of ${ }^{14} \mathrm{C}$ and ${ }^{3} \mathrm{H}$ were $90-95 \%$ and $50-55 \%$, respectively.

Autoradiography. Twelve-day-old cultures were fluid changed into $2 \mathrm{ml}$ fresh complete medium supplemented with $70 \mu \mathrm{Ci}$ of $\left[{ }^{3} \mathrm{H}\right]$-AAF $\left(2 \times 10^{-5} \mathrm{M}\right)$. Twenty-four hours later, the media were aspirated and the cultures washed $6 \times$ with $2 \mathrm{ml}$ Tris-HCl buffer, $\mathrm{pH}$ 7.4, and prepared for routine autoradiography by fixation with neutral buffered formalin; by exposure to $\beta$-particle sensitive Eastman Kodak AR-10 stripping film for 80 days, at $4^{\circ} \mathrm{C}$ in darkness (Koch and Leffert, 1974), followed by routine development for microscopy.

Statistical analyses. Linear regression curves and LineweaverBurk analyses were calculated using GraphPad and Prism Software (La Jolla, CA). Mean values, SD, and $p$ values were calculated using Microsoft Excel.

\section{RESULTS}

Uptake and Binding of AAF From the Culture Medium

$\mathrm{N}$-acetyl-2-aminofluorene was concentrated into cells from the extracellular medium. A log-log plot of the steady-state of intracellular acid-soluble $\left[{ }^{14} \mathrm{C}\right]-\mathrm{AAF},[\mathrm{AAF}]_{\mathrm{i}}$, as a function of the initial extracellular concentration of AAF in the medium $\left(6 \times 10^{-8}\right.$ $\left.2 \times 10^{-5} \mathrm{M}\right),[\mathrm{AAF}]_{\mathrm{o}}$, yielded a linear absorption curve with a firstorder reaction constant. These results are shown in Figure 1.

Binding of $\left[{ }^{14} \mathrm{C}\right]$-AAF to acid-insoluble material was linearly proportional to the numbers of cells per culture (from $\left.0.8 \times 10^{5}-1.0 \times 10^{6}\right)$, and proportional to $[\mathrm{AAF}]_{\text {。 with a rank }}$ order of $2 \times 10^{-5} \mathrm{M}>6 \times 10^{-6} \mathrm{M}>6 \times 10^{-7} \mathrm{M}>6 \times 10^{-8} \mathrm{M} \quad$ AAF (Supplementary Figure 1). These results indicated that the levels of bound $\left[{ }^{14} \mathrm{C}\right]$-AAF were not affected by cell densitydependent conditioning of the media (Leffert et al., 1977).

The rates and the levels of binding and uptake of the $\left[{ }^{14} \mathrm{C}\right]-$ or $\left[{ }^{3} \mathrm{H}\right]$-labeled forms of AAF were virtually identical over an $[\mathrm{AAF}]_{\mathrm{o}}$ of $6 \times 10^{-8}-2 \times 10^{-5} \mathrm{M}$. Thus, in 3-day-old cultures, similar quantitative and qualitative results were obtained when either $\left[{ }^{14} \mathrm{C}\right]-\mathrm{AAF}$ or $\left[{ }^{3} \mathrm{H}\right]-\mathrm{AAF}$ were incubated with the cells over a $24 \mathrm{~h}$ period (Supplementary Figure 2). Acid-insoluble radiolabeled material in hepatocytes increased 1- to 270-fold in proportion to the $[\mathrm{AAF}]_{\mathrm{o}}$ (panel A, lower and upper curves). By comparison, the levels of acid-soluble $[\mathrm{AAF}]_{\mathrm{i}}$ were augmented 4- to 1300-fold in proportion to the $[\mathrm{AAF}]_{\mathrm{o}}$ (panel $\mathrm{B}$, lower and upper curves). $[\mathrm{AAF}]_{\mathrm{i}}$ reached steady states between 6 and $24 \mathrm{~h}$ at all $\left[{ }^{14} \mathrm{C}\right]-\mathrm{AAF}$ or $\left[{ }^{3} \mathrm{H}\right]$-AAF concentrations tested. The specific nature of the bound material and its relationships to $[\mathrm{AAF}]_{\mathrm{i}}$ are described in the second report (Koch et al., 2018).

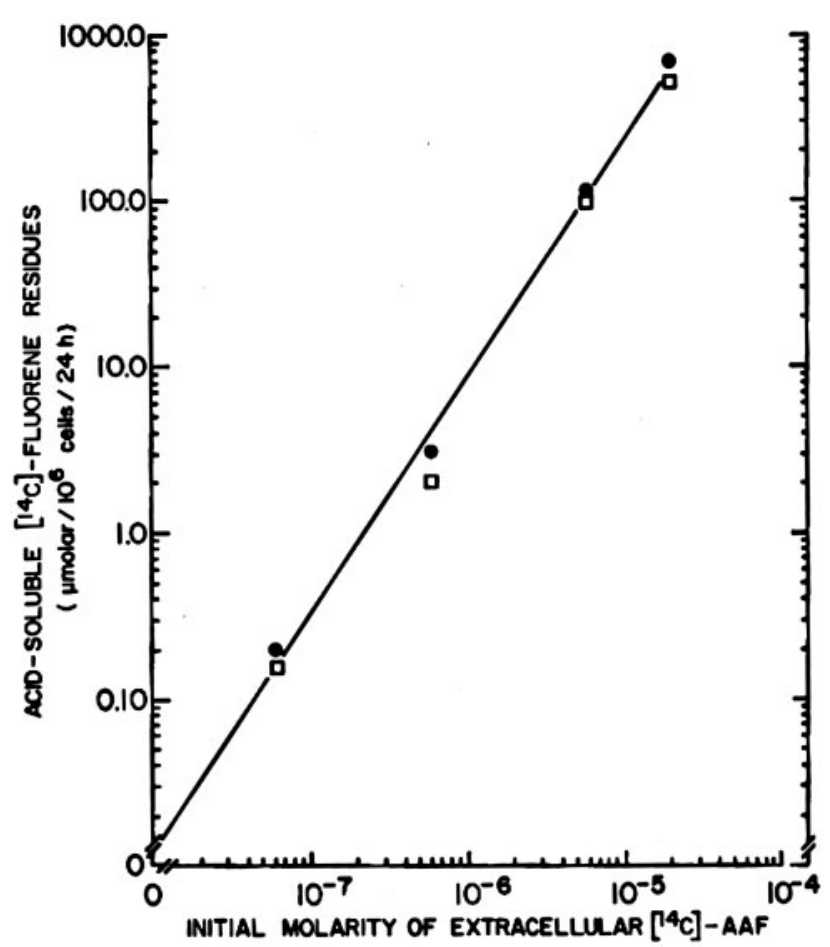

Figure 1. Uptake of N-acetyl-2-aminofluorene (AAF) from culture media. Acidsoluble $\left[{ }^{14} \mathrm{C}\right]$-AAF was measured in days $3-4$ cultures $\left(N_{0}=3.5 \times 10^{5}\right.$ cells $/$ dish $)$ following a $24 \mathrm{~h}$ exposure to a range of extracellular AAF concentrations $\left(6 \times 10^{-8}-2 \times 10^{-5} \mathrm{M}\right)$. Two independent platings were performed $(\bullet, \square)$. The results are expressed as soluble fluorene residues $\left(\mu \mathrm{M} / 10^{6}\right.$ cells $\left./ 24 \mathrm{~h}\right)$ on the $y$ axis, as a function of the added AAF concentrations on the $x$-axis. The data were analyzed by linear regression: $r=0.98(p<.0001)$.

Kinetics of the Disappearance of AAF From the Culture Medium When $2 \times 10^{-5} \mathrm{M}\left[{ }^{3} \mathrm{H}\right]$-AAF was added to 3 -day-old cultures, $54 \%$ of the radiolabeled extracellular AAF disappeared from the culture medium within $24 \mathrm{~h}$ (see inset to Figure 2). The rate of disappearance followed zero-order kinetics $\left(2.3 \mathrm{nmol} \mathrm{AAF} / 10^{6}\right.$ cells/h $\approx 12 \mu \mathrm{g} \mathrm{AAF} / 10^{6}$ cells/day).

Chemical Nature and Kinetics of Secretion of the Metabolites of AAF in 3- to 4-Day-Old Cultures

When $2 \times 10^{-5} \mathrm{M}\left[{ }^{3} \mathrm{H}\right]$-AAF was added to the cultures, six $\mathrm{H}_{2} \mathrm{O}$ soluble radiolabeled metabolites were secreted into the culture media over $24 \mathrm{~h}$ (see the main panel of Figure 2): O,N-hydroxylated-AAF (N-OH-AAF, $4.8 \%$ of the total); $\bullet$, ring-hydroxylatedAAF (7-OH-AAF), 12\%; $\square, 5-\mathrm{OH}-\mathrm{AAF}, 16.8 \% ; \mathrm{X}, 3-\mathrm{OH}-\mathrm{AAF}$, 9.1\%; $\mathbf{\square}, 1-\mathrm{OH}-\mathrm{AAF}, 0.2 \%$; and $\Delta$, deacetylated aminofluorene $(\mathrm{AF}, \approx 3 \%)$. Unidentified metabolites $(\boldsymbol{\nabla}, 9.2 \%)$ migrating at the solvent fronts of the TLC plates were also observed. No metabolites of AAF were detected in fresh plating media incubated with $\left[{ }^{3} \mathrm{H}\right]-\mathrm{AAF}$, but without cells, or in centrifuged cell-free conditioned media obtained from unlabeled 3-day-old sister cultures, and subsequently incubated with $\left[{ }^{3} \mathrm{H}\right]-\mathrm{AAF}$ for $24 \mathrm{~h}$ under regular culture conditions, but without cells. These controls eliminated the possibility that spurious AAF metabolites had formed and were released as a result of chemical oxidation or leakage of P450 enzymes from dying or floating cells in the centrifuged culture media.

Individual metabolites appeared at different rates. At least four were produced as linear functions of time: unidentified ones, from 0 to $5 \mathrm{~h}$; 7-OH-AAF, from 0 to $24 \mathrm{~h}$; $\mathrm{AF}$, from 1 to $24 \mathrm{~h}$, after an initial burst from 0 to $1 \mathrm{~h}$; and 1-OH-AAF from 0 to $24 \mathrm{~h}$. 


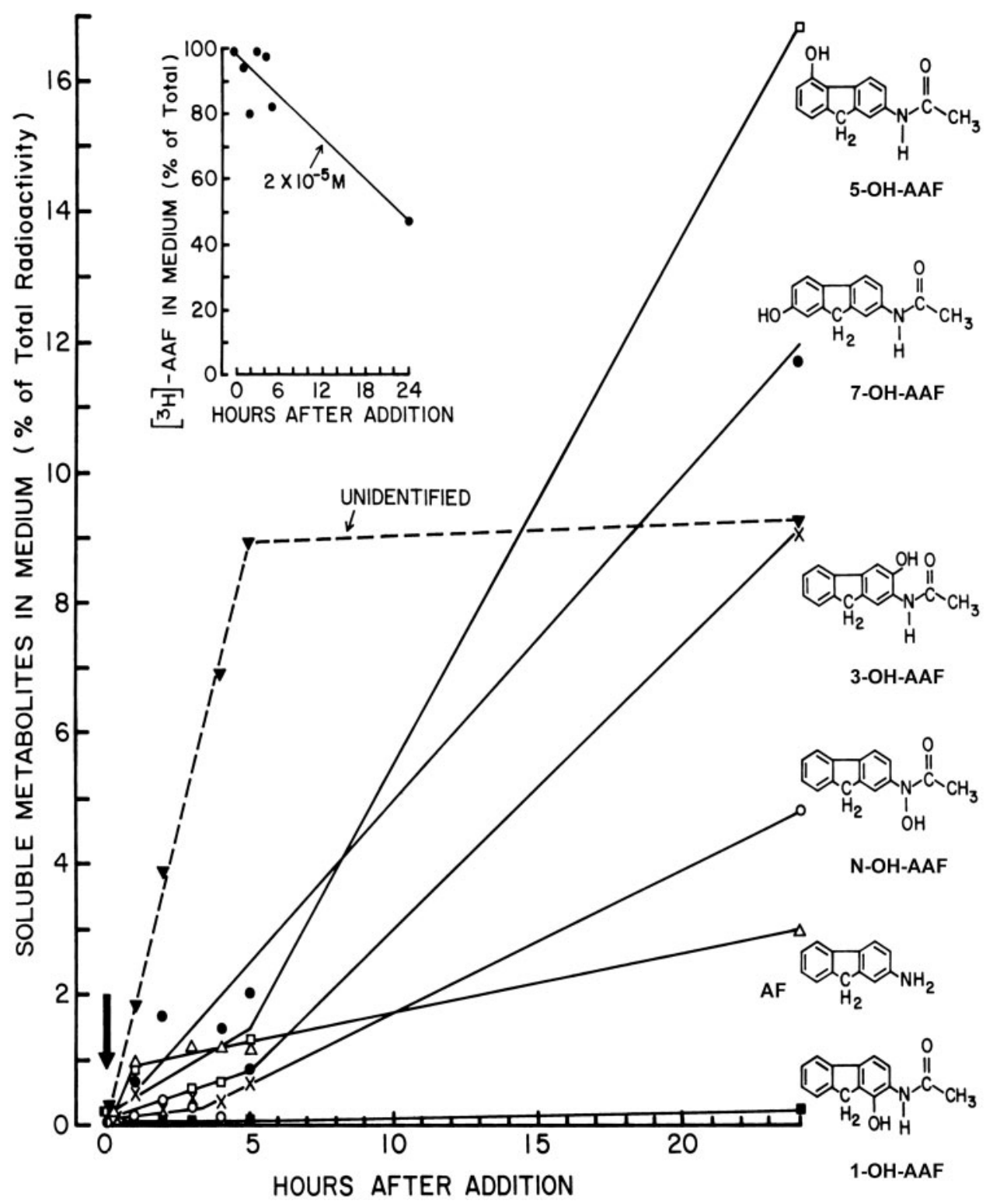

Figure 2. Nature and rates of secretion of AAF metabolites. Three-day-old cultures $\left(\mathrm{N}_{0}=4.0 \times 10^{5}\right.$ cells/dish) were incubated with $40 \mathrm{nmol}\left[{ }^{3} \mathrm{H}\right]$ - $\mathrm{AAF}\left(4000 \mathrm{dpm}\right.$ pmol $\left.{ }^{-1}\right)$ per $2 \mathrm{ml}$ medium per dish (initial AAF concentration $=2 \times 10^{-5} \mathrm{M}$ ). Culture fluids were sampled at the indicated times between zero $(\downarrow)$ at the start of incubation and $24 \mathrm{~h}$ ( $x$-axis), and analyzed for AAF disappearance (inset), and $\mathrm{H}_{2} \mathrm{O}$-soluble hydroxylated and deacetylated metabolites ( $y$-axis), as described in the Materials and Methods section. Each curve is annotated with a contiguous diagram of the structure of each metabolite: $\square, 5-\mathrm{OH}-\mathrm{AAF} ; \bullet, 7-\mathrm{OH}-\mathrm{AAF}$; $\mathbf{\nabla}$, unidentified at solvent front; $\mathrm{X}$, 3-OH-AAF; O, N-OH-AAF; $\Delta, \mathrm{AF}$; and, $\mathbf{\square}, 1-\mathrm{OH}-\mathrm{AAF}$ (top to bottom). Parameters obtained from linear regression analysis of the inset curve: $r=0.92$ ( $p<.002$ ).

Within the range of $24 \mathrm{~h}$, only the rate of formation of unidentified metabolites at the solvent front appeared to plateau between 5 and $24 \mathrm{~h}$. In contrast, no plateaus were observed in the linear rate curves for $7-\mathrm{OH}-\mathrm{AAF}$ and $1-\mathrm{OH}-\mathrm{AAF}$ within the $24 \mathrm{~h}$ period. The metabolites 5-OH-AAF, 3-OH-AAF, and N-OH-AAF were secreted biphasically without plateaus. In the latter curves, the low initial rates were linear from $\approx$ zero-time through $4-5 \mathrm{~h}$. Thereafter, the rates of secretion were augmented 2- to 3-fold at $\approx 5 \mathrm{~h}$ for 5 -OH-AAF, 3-OH-AAF, and $\mathrm{N}-\mathrm{OH}$ $\mathrm{AAF}$, respectively, suggestive of enzyme induction.

Growth Cycle Changes in the Binding and Secretion of Metabolites of AAF

Total AAF binding fell exponentially $(\approx 70 \%)$ as a function of the culture age during the 0-13 days growth cycle (Figure 3A).
During the same time interval, this decline was proportional to an exponential decline $(\approx 60 \%)$ in the levels of secreted $\mathrm{N}-\mathrm{OH}-$ $\mathrm{AAF}$ (consistent with the rate-limiting role of $\mathrm{N}-\mathrm{OH}-\mathrm{AAF}$ in AAF activation).

The overall levels of secreted metabolites varied during the 0-13 days growth cycle, with a rank quantitative order that was unchanged: 5-OH-AAF $>$ 7-OH-AAF $>3-\mathrm{OH}-\mathrm{AAF}>\mathrm{N}-\mathrm{OH}-\mathrm{AAF}>$ $\mathrm{AF}>1-\mathrm{OH}-\mathrm{AAF}$ (Figure $3 \mathrm{~B}$ ). Between days 5-13, daily production capacities (see the legend to Figure $3 \mathrm{~B}$ ) fell exponentially in four instances to $45 \%$ (N-OH-AAF), 38\% (3-OH-AAF), 11\% (AF), and $3 \%$ (1-OH-AAF) of the day 5 levels, respectively. In contrast, over the same time interval, 5-OH-AAF and 7-OH-AAF varied biphasically, falling to levels of $48 \%$ and $44 \%$, respectively, on day 9 , but increasing to levels of $59 \%$ and $69 \%$, respectively, by day 13 . 


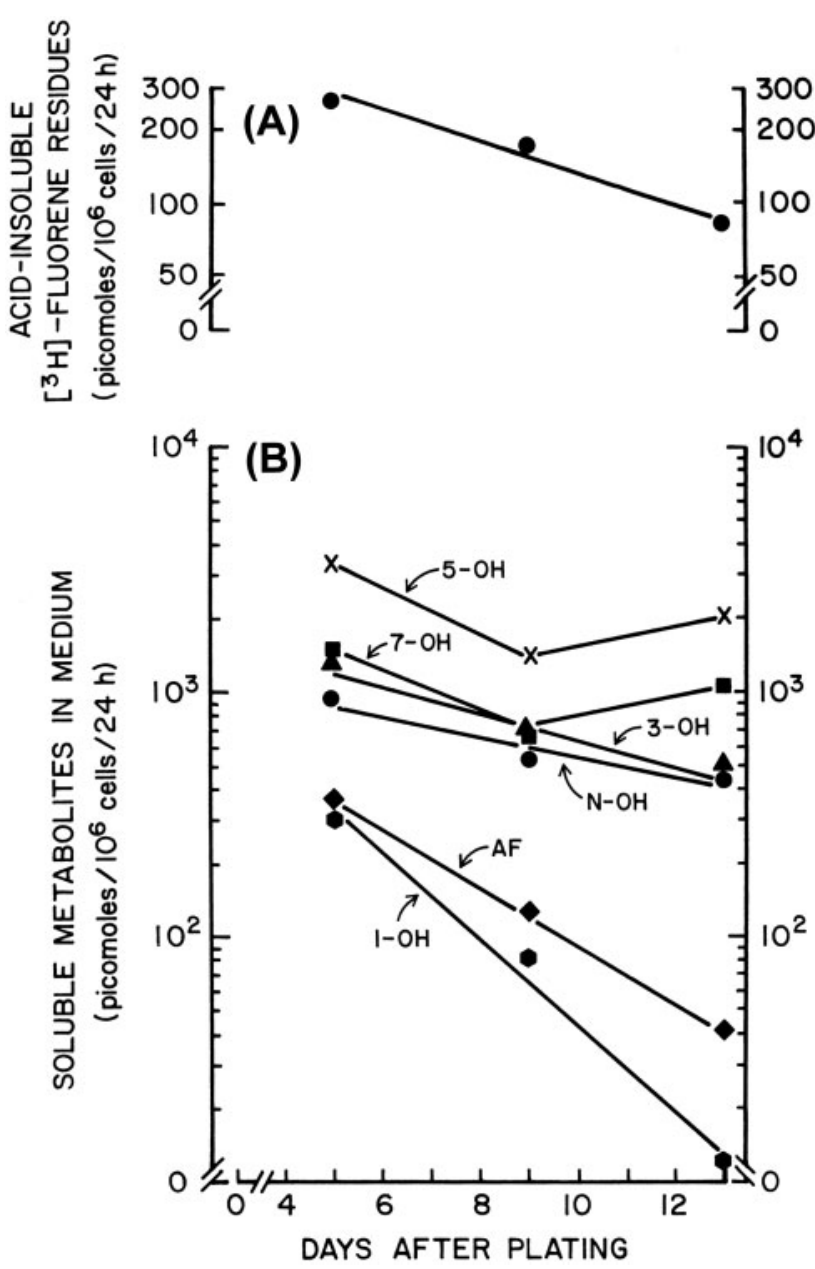

Figure 3. Growth cycle dependence of AAF binding and AAF metabolite secretion. Hepatocytes were plated exactly as described in the Primary hepatocyte culture section. On days 4,8 , or 12 postplating ( $x$-axis [Days After Plating]), the initial plating media were removed and replaced with $2 \mathrm{ml}$ fresh plating media supplemented with $2 \times 10^{-4} \mathrm{M}\left[{ }^{3} \mathrm{H}\right]$-AAF. These culture media were harvested $24 \mathrm{~h}$ later on days 5,9 , or 13 per time point (x-axis). A, Acid-insoluble fluorene residues (y-axis, top; picomoles $/ 10^{6}$ cells $\left./ 24 \mathrm{~h}\right)$. B, Soluble metabolites in the medium (y-axis, bottom; picomoles $/ 10^{6}$ cells $/ 24 \mathrm{~h}$ ), isolated by thin layer chromatography as described in the Materials and Methods section (individual metabolites are annotated for each curve). The relative production capacity (\%) over the 5- to 13-day period was determined for each metabolite at each time point from the equation: $\left(100-\left[\left\{(\% \text { production })_{\text {MEASUREMENT DAY }}-(\% \text { production })_{\text {DAY } 5}\right\} /\left\{(\% \text { production })_{\text {DAY } 5}\right\}\right]\right) \times(100)$.

\section{Lineweaver-Burk Analyses}

The levels of individual metabolites of AAF secreted in 3- to 4day-old cultures were proportional to $[\mathrm{AAF}]_{\text {。 }}$ over a 4-log $[\mathrm{AAF}]_{\text {。 }}$ range of $6 \times 10^{-8}-2 \times 10^{-5} \mathrm{M}$. This is shown in Figure 4 . Two patterns of concentration-dependent curves of metabolite secretion were obtained: AF alone was secreted as a linear curve over the entire concentration range; whereas 1-, 3-, 5-, 7-, and N-OHAAF followed biphasic secretion curves between $6 \times 10^{-8}$ $2 \times 10^{-7} \mathrm{M}$ and $2 \times 10^{-7}-2 \times 10^{-5} \mathrm{M}$, with the former slope being $<$ the latter.

When the different data sets were analyzed by LineweaverBurk plots (Figure 5), the following high-affinity $K_{\text {m[APPARENT] DAY } 4}$ constants were obtained: $1.7 \times 10^{-7} \mathrm{M}, 1.1 \times 10^{-7} \mathrm{M}, 3.1 \times 10^{-7} \mathrm{M}$, $2.7 \times 10^{-7} \mathrm{M}$, and $1.6 \times 10^{-7} \mathrm{M}$, for metabolites 1-, 3-, 5-, 7-, and $\mathrm{N}$ -

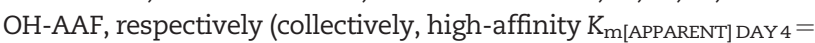
$\left.1.64 \pm 0.7 \quad(\mathrm{SD}) \times 10^{-7} \mathrm{M}, \quad p<.05\right)$. The following low-affinity

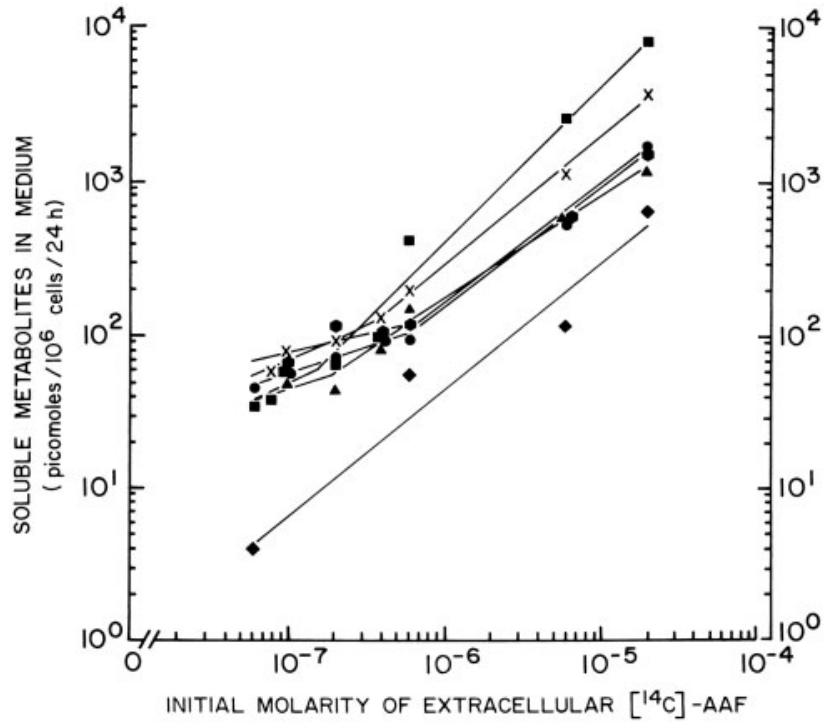

Figure 4. AAF metabolite secretion as a function of the initial AAF concentration. Day 3 cultures $\left(N_{0}=3.5 \times 10^{5}\right.$ cells/dish) were incubated for a $24 \mathrm{~h}$ period with $\left[{ }^{14} \mathrm{C}\right]$-AAF $\left(6 \times 10^{-8}-2 \times 10^{-5} \mathrm{M}\right)$, at which time the metabolites in the medium were measured. Symbols are the same as those annotated in Figure 5. [S], Concentration of soluble metabolites in the medium ( $y$-axis; picomoles $/ 10^{6}$ cells/24h). Initial molarity of extracellular $\left[{ }^{14} \mathrm{C}\right]-\mathrm{AAF}$ ( $\mathrm{x}$-axis).

$\mathrm{K}_{\mathrm{m} \text { [APPARENT] DAY } 4}$ constants were obtained: $3.9 \times 10^{-5} \mathrm{M}$, $2.6 \times 10^{-5} \mathrm{M}, 4.4 \times 10^{-5} \mathrm{M}, 4.0 \times 10^{-5} \mathrm{M}$, and $4.1 \times 10^{-5} \mathrm{M}$ for 1-, 3-, 5-, 7-, and N-OH-AAF, respectively (collectively, low-affinity $\left.\mathrm{K}_{\mathrm{m} \text { [APPARENT] DAY } 4}=3.25 \pm 0.65(\mathrm{SD}) \times 10^{-5} \mathrm{M}, p<.05\right)$. Extrapolation of each family of high- and low-affinity $K_{\mathrm{m} \text { [APPARENT] DAY } 4}$

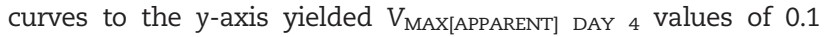
and $1000 \mathrm{nmol} / 10^{6}$ cells $/ 24 \mathrm{~h}$, respectively. The curve for the metabolite AF yielded a $K_{\text {m[APPARENT] DAY } 4}=9.6 \times 10^{-5} \mathrm{M}$, and a $\mathrm{V}_{\text {MAX[APPARENT] DAY } 4}=4.7 \mathrm{nmol} / 10^{6} \mathrm{cells} / 24 \mathrm{~h}$.

\section{Localization of Bound AAF}

When quiescent 12-day-old cultures were incubated for $24 \mathrm{~h}$ with $2 \times 10^{-5} \mathrm{M}\left[{ }^{3} \mathrm{H}\right]-\mathrm{AAF}$ and subsequently subjected to autoradiography, the resulting tritium grains (although individually indistinguishable given the length of the development time) localized preferentially to the cytoplasm of hepatocytes in monolayer aggregates (Figure 6). Hepatocyte nuclei showed markedly fewer grains than the cytoplasm, consistent with roughly 210-fold reductions in the nuclear levels of covalently bound DNA adducts under these conditions (Koch et al., 2018); some of these $\left[{ }^{3} \mathrm{H}\right]$-grains were also detected in mitotic figures. Interspersed nonparenchymal cells showed scant cytoplasmic and far fewer nuclear grains than hepatocytes.

After $24 \mathrm{~h}$ exposure to $2 \times 10^{-5} \mathrm{M}$ AAF, cultured hepatocytes (day 13) showed no significant cytotoxicity as revealed by the: (a) absence of detached floating cells (Howard et al., 1981); (b) levels of DNA replication that were statistically similar to control levels (Koch et al., 2018), and presence of mitotic hepatocytes (Figure 6); and (c) significant conversion of extracellular levels of $2 \times 10^{-4} \mathrm{M}$ AAF to the soluble metabolite $\mathrm{N}-\mathrm{OH}-\mathrm{AAF}$ (Figure 3), and of radiolabeled AAF to covalently bound macromolecular DNA and protein adducts (Koch et al., 2018). 


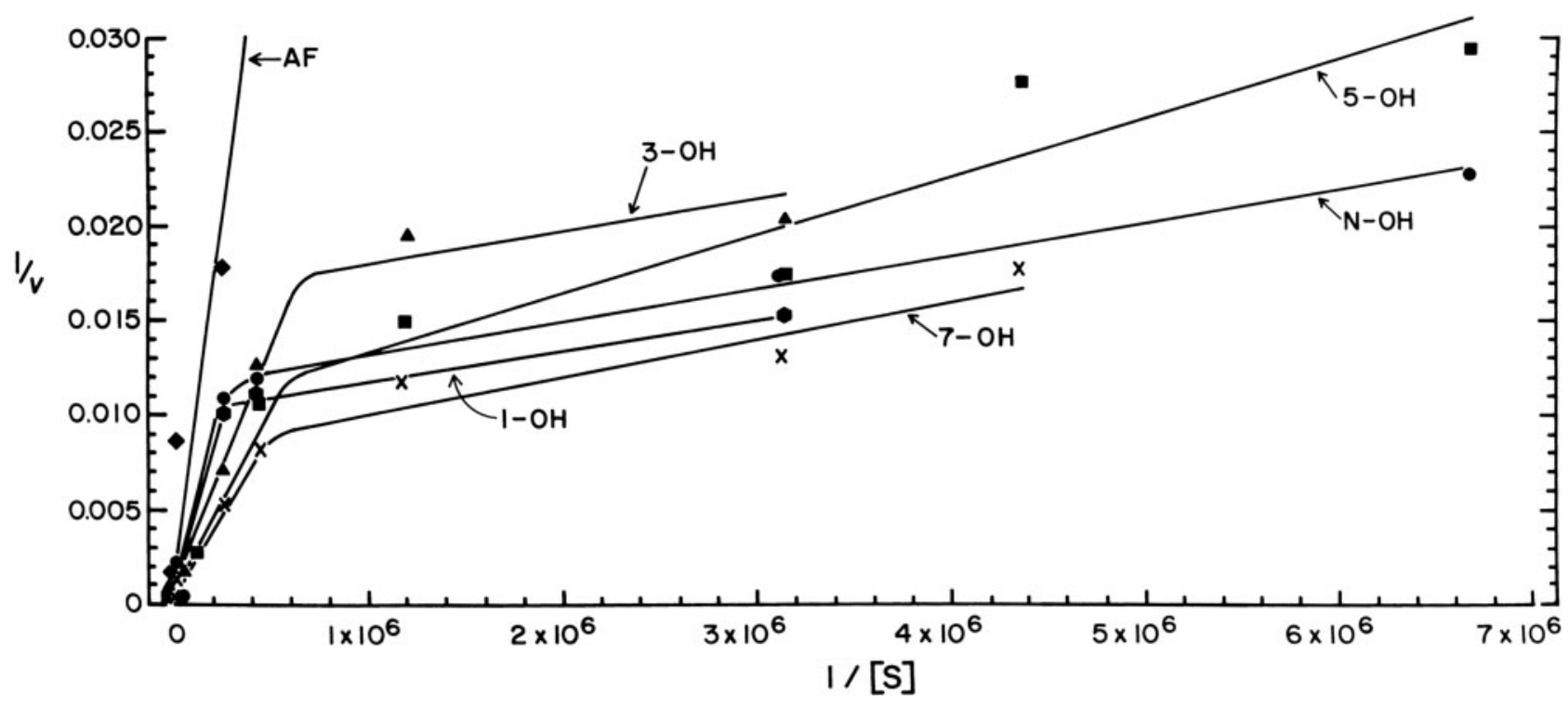

Figure 5. Lineweaver-Burk analyses of AAF metabolite secretion. The $24 \mathrm{~h}$ data points were taken from 4-day-old cultures in Figure 4. These data were plotted as: $1 / v$ (y-axis), with $v=$ picomoles $/ 10^{6}$ cells $/ 24 \mathrm{~h}$; and $1 /[\mathrm{S}]$ ( $\mathrm{x}$-axis), with $[\mathrm{S}]=$ initial molarity of extracellular $\left[{ }^{14} \mathrm{C}\right]$-AAF. Metabolites are annotated for each curve in the figure.
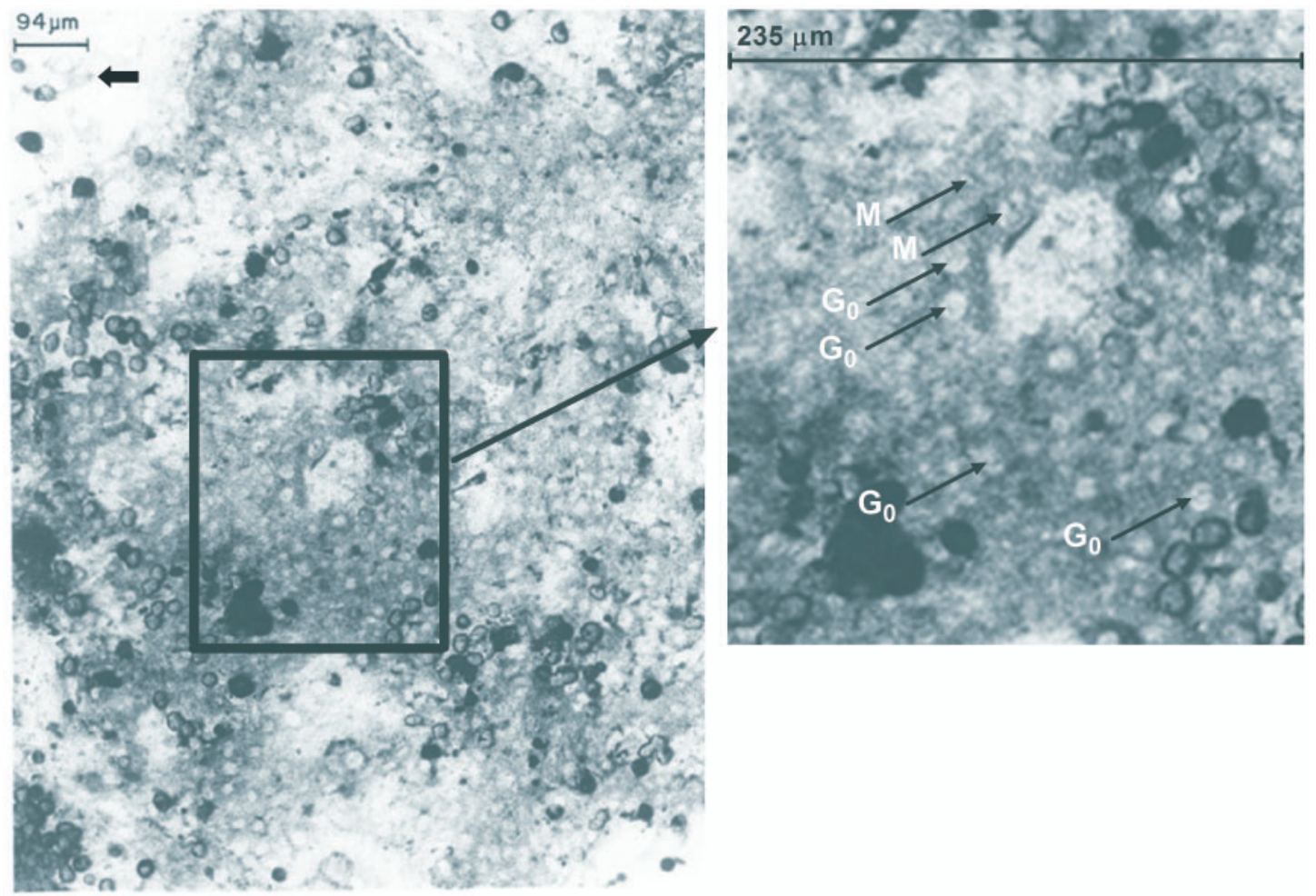

Figure 6. In situ autoradiography of covalently bound metabolites of AAF in day 13 cultures. Hepatocytes were plated exactly as described in the Primary hepatocyte culture section. Twelve days postplating, the initial plating media were removed and the culture fluids were replaced with $2 \mathrm{ml}$ fresh plating media supplemented with $70 \mu \mathrm{Ci}$ of $\left[{ }^{3} \mathrm{H}\right]-\mathrm{AAF}\left(2 \times 10^{-5} \mathrm{M}\right)$. Twenty-four hours later, the media were aspirated and the cultures were washed $6 \times$ with $2 \mathrm{ml}$ Tris-HCl buffer, $\mathrm{pH} 7.4$, and prepared for autoradiography by fixation with neutral buffered formalin, followed by an 80 days exposure at $4^{\circ} \mathrm{C}$ in darkness; and subsequent development (Koch and Leffert, 1974 ). A representative photomicrograph of an unstained culture is shown in the left-hand panel. The short thick arrow (upper left corner) points to a very sparsely labeled nonparenchymal cell. The INSET, enlarged in the right-hand panel, shows [ $\left.{ }^{3} \mathrm{H}\right]$-fluorene labeled metaphase (M) chromosomes (long arrows pointing to dark linear structures tilted $45^{\circ}$ leftward inside hepatocytes); and $\mathrm{G}_{0}$ cells (long arrows pointing to hepatocytes with densely labeled cytoplasm, and to nuclei with reduced levels of centrally located grains). The horizontal bars at the top of each panel give the dimensions in microns along the surface of the monolayer. (Modified from Koch and Leffert, 1980, and used by permission of John Wiley and Sons.) 


\section{DISCUSSION}

The investigations reported here have revealed several aspects of the processing and pharmacological properties of the formation of AAF metabolites, key physicochemical constants, and the two principal locations of AAF metabolism inside normal primary adult rat hepatocytes in long-term cultures. Metabolite formation was surveyed over an $[\mathrm{AAF}]_{\text {。 }}$ range of $2 \times 10^{-8}$ $2 \times 10^{-4} \mathrm{M}$, wider than the concentration ranges reported previously (Guzelian et al., 1977; Michalopoulos and Pitot, 1975; Michalopoulos et al., 1976; Monteith et al., 1988; Spilman and Byard, 1981).

A first-order AAF absorption reaction constant suggested that AAF uptake occurred by simple diffusion across plasma membranes as a function of the partition coefficients of the lipid phases. However, as supported by kinetic studies and by Lineweaver-Burk analyses, a component of carrier-mediated transport was also evident as indicated by the appreciable concentration of TCA-soluble $\left[{ }^{14} \mathrm{C}\right]$-fluorene residues inside cells. Zero-order metabolism of AAF $\left(2 \times 10^{-5} \mathrm{M}\right)$ indicated that enzymatic machinery was present in excess, in agreement with a previous report (Spilman and Byard, 1981).

AAF metabolism into radiolabeled soluble and bound intracellular fluorene residues depended upon cell numbers, growth-state and culture age. These dependencies could not be attributed to the use of the different isotopes of AAF because $\left[{ }^{3} \mathrm{H}\right]$-AAF ([ring $\left.\mathrm{G}^{3} \mathrm{H}\right]-\mathrm{N}$-acetyl-2-aminofluorene) and $\left[{ }^{14} \mathrm{C}\right]-\mathrm{AAF}$ (N-acetyl-9-[ $\left.{ }^{14} \mathrm{C}\right]$-2-aminofluorene) appeared to be utilized identically by the cells under various conditions (consistent with the chemical location of the bulk of the ${ }^{3} \mathrm{H}$ on the C9-position of the fluorene ring). Other metabolites were undetectable and uncharacterized: for instance, 9-OH-AAF and an "unidentified" group, respectively; HPLC analyses will be needed to detect and identify them (Ryzewski and Malejka-Giganti, 1982). The secretion of $\mathrm{N}-\mathrm{OH}-\mathrm{AAF}$, the rate limiting step in procarcinogen activation and evidence of sustained hepatocyte differentiation, was observed through day 13; varying results were obtained in other primary hepatocyte systems (Guzelian et al., 1977; Michalopoulos and Pitot, 1975; Michalopoulos et al., 1976; Monteith et al., 1988; Spilman and Byard, 1981). However, the origin of hepatocytes and the conditions of long-term culture used here differed from those of the short-term cultures.

Pharmacologic evidence of two principal AAF metabolizing systems was observed: System I (high-affinity and low-velocity), with a $K_{\mathrm{m} \text { [APPARENT] }}=1.64 \times 10^{-7} \mathrm{M}$ and $\mathrm{V}_{\text {MAX[APPARENT] }}=$ $0.1 \mathrm{nmol} / 10^{6}$ cells $/ 24 \mathrm{~h}$; and System II (low-affinity and highvelocity), with a $K_{\mathrm{m} \text { [APPARENT] }}=3.2510^{-5} \mathrm{M}$ and $\mathrm{V}_{\text {MAX[APPARENT] }}=$ $1000 \mathrm{nmol} / 10^{6}$ cells $/ 24 \mathrm{~h}$. AF metabolites were generated from AAF by a third system with a $K_{\text {m[APPARENT] }}$ and V VAX[APPARENT] DAY 4 of $9.6 \times 10^{-5} \mathrm{M}$ and $4.7 \mathrm{nmol} / 10^{6}$ cells $/ 24 \mathrm{~h}$, respectively.

The biochemical bases of these observations are currently unclear. However, the third metabolism system, which generates AF from AAF, probably involves an arylacetamide deacetylase (AADA) associated with the endoplasmic reticulum of hepatocytes (Trickett et al., 2001). Hepatocyte AADA plays roles in the assembly of very-low-density lipoprotein (VLDL), an extracellular inhibitor of normal rat hepatocyte proliferation (Leffert and Weinstein, 1976). Serum VLDL levels are inversely correlated with hepatocyte proliferation (Leffert and Koch, 1977; Leffert and Weinstein, 1976) and significant reductions are reported in human patients with HCC (Ooi et al., 2005).

One plausible explanation for the two principal AAF metabolizing systems is that alternatively spliced Cyp1A2 isozymes, like the single-copy human gene (Allorge et al., 2003; GeneCards
Human Gene Database, 2018; Schweikl et al., 1993; Zhou et al., 2010), operate in adult rat hepatocytes: one in the nucleus (System I [with one set of $K_{m}$ and $V_{\text {MAX }}$ values]); and the other in the cytoplasm (System II [with another set of $K_{m}$ and $V_{\text {MAX }}$ values]). Although neither AAF metabolism via nonparenchymal cells ( $\leq 5 \%$ of the total population) nor bystander effects (Koch and Leffert, 2015) were rigorously excluded, autoradiography with $\left[{ }^{3} \mathrm{H}\right]$-AAF demonstrated dissimilar distributions of covalently bound intracellular macromolecular adducts (cytoplasm $\gg$ nucleus), supporting $\mathrm{N}-\mathrm{OH}-\mathrm{AAF}$-generating Cyp1A2 metabolic activity at both hepatocellular sites. However, little is known about the subcellular locations of rat and human hepatocyte Cyp1A2 isozymes (Annalora et al., 2017); therefore, the autoradiographic findings are also consistent with one differentially distributed isozyme, wherein the nuclear and cytoplasmic milieu dictate the properties of the $K_{m}$ and $V_{\text {MAX }}$ of the enzyme.

In fact, partial nuclear localization of Cyp1A2 is predicted from searches using cNLS Mapper setting cut-off scores at 7.0 (Kosugi et al., 2009). This program identifies two 90\% homologous monopartite nuclear localization signals (NLSs [Nigg et al., 1991]) at aa positions 451-460 (glgkrrcige) and 452-461 (gmgkrrcige) in the $75 \%$ homologous alignments of the entire rat (GenBank [NP_036673.3]) and human (UniProt P05177) proteins, respectively; each decapeptide NLS is 53 amino acids from its Cterminus (Supplementary Figure 3), far from the enzymes' active sites (Zhou et al., 2010); and, as expected for NLSs, both have basic isoelectric points of 9.803 (Kozlowski, 2016). Observations in the accompanying report further support intranuclear metabolism of AAF directed by NADPH-dependent Cyp1A2 (Koch et al., 2018).

Alternatively, the concerted operation of several cytochrome P450s might underlie the observations reported here. For example, apart from the rat Cyp1A2 isozyme, (NP_036673.3), rat hepatic microsomal extracts contain five additional cytochrome P450s (designated Cyp2B1 [NP_001128316.1], Cyp1A1 [NP_036672.2], Сyp2B2 [NP_001185605.1], Cyp2C6 [P05178.2], and Cyp3A2 [NP_695224.2]); and, in cell-free systems reconstituted with purified microsomal proteins, the Cyp1A1 and Cyp1A2 isozymes produce most but not all of the hydroxylated metabolites of AAF (Aström et al., 1986; Guengerich et al., 1982; Nebert et al., 1991). With the exception of rat Cyp1A2, cNLS Mapper failed to detect NLS domains in the primary sequences of the five additional cytochrome P450s (data not shown). Studies with human liver microsomes have also shown biphasic kinetics for 7-OHAAF formation, further suggesting that individual metabolites might be produced by different P450s (McManus et al., 1983). Together with enzyme induction of 5-OH-AAF, 3-OH-AAF, and $\mathrm{N}-\mathrm{OH}-\mathrm{AAF}$, mixed activation of different subtypes might have accounted for the U-shaped curves of 7- and 5-OH-AAF metabolite formation during the growth cycle.

It is also possible that differential substrate accessibility, not only particularly of AAF, N-OH-AAF, and AF, but also potentially of the other metabolites might occur inside hepatocytes, because altered enzyme activity and polypeptide composition of rat hepatic endoplasmic reticulum have been reported following acute exposure to AAF (Kaderbhai et al., 1982). Further investigations will be required to address these unresolved issues.

\section{SUPPLEMENTARY DATA}

Supplementary data are available at Toxicological Sciences online. 


\section{FUNDING}

This work was supported by grants from the American Cancer Society (IN93R [to K.S.K.]); the National Institutes of Health (CA29540, CA26851 [to Stewart Sell], and AM28215, AM28392 [to H.L.L.]); and the UCSD Academic Senate (RP118B [to H.L.L. and K.S.K.]).

\section{ACKNOWLEDGMENT}

We thank Hal Skelly for additional technical assistance.

\section{REFERENCES}

Allorge, D., Chevalier, D., Lo-Guidice, J. M., Cauffiez, C., Suard, F., Baumann, P., Eap, C. B., and Broly, F. (2003). Identification of a novel splice-site mutation in the CYP1A2 gene. Br. J. Clin. Pharmacol. 56, 341-344.

American Cancer Society. (2018). Liver Cancer. http://www. cancer. org/acs/groups/cid/documents/webcontent/003114pdf.pdf

Annalora, A. J., Marcus, C. B., and Iversen, P. L. (2017). Alternative splicing in the cytochrome $\mathrm{P} 450$ superfamily expands protein diversity to augment gene function and redirect human drug metabolism. Drug Metab. Dispos. 45, 375-389.

Aström, A., Birberg, W., Pilotti, A., and DePierre, J. W. (1986). Induction of different isozymes of cytochrome P-450 and of microsomal epoxide hydrolase in rat liver by 2 -acetylaminofluorene and structurally related compounds. Eur. J. Biochem. 154, 125-134.

Bartsch, H., Dworkin, M., Miller, J. A., and Miller, E. C. (1972). Electrophilic N-acetoxyaminoarenes derived from carcinogenic $\mathrm{N}$-hydroxy-N-acetylaminoarenes by enzymatic deacetylation and transacetylation in liver. Biochim. Biophys. Acta 286, 272-298.

Cancer: A Comprehensive Treatise, Vol. 1, Etiology: Chemical and Physical Carcinogenesis (F.F. Becker, Ed.) Plenum Press, New York and London; 1975.

Cramer, J. W., Miller, J. A., and Miller, E. C. (1960). A new metabolic reaction observed in the rat with the carcinogen 2-acetylaminofluorene. J. Biol. Chem. 235, 885-888.

DeBaun, J. R., Miller, E. C., and Miller, J. A. (1970). N-hydroxy-2acetylaminofluorene sulfotransferase: Its probable role in carcinogenesis and in protein-(methion-S-yl) binding in rat liver. Cancer Res. 30, 577-595.

GenBank. (2018). NCBI: Protein. https://www.ncbi.nlm.nih.gov/ protein? cmd=retrieve.

GeneCards Human Gene Database. (2018). CYP1A2. http://www. genecards.org/cgi-bin/carddisp.pl?gene=CYP1A2 .

Guengerich, F. P., Dannan, G. A., Wright, S. T., Martin, M. V., and Kaminsky, L. S. (1982). Purification and characterization of liver microsomal cytochromes P-450: Electrophoretic, spectral, catalytic, and immunochemical properties and inducibility of eight Isozymes Isolated from rats treated with phenobarbital or 1d-naphthoflavone. Biochemistry 21, 6019-6030.

Gutmann, H. R., Galitski, S. B., and Foley, W. A. (1967). The conversion of noncarcinogenic aromatic amides to carcinogenic arylhydroxamic acids by synthetic N-hydroxylation. Cancer Res. 27, 1443-1455.

Guzelian, P. S., Bissell, D. M., and Meyer, U. A. (1977). Drug metabolism in adult rat hepatocytes in primary monolayer culture. Gastroenterology 72, 1232-1239.
Howard, P. C., Casciano, D. A., Beland, F. A., and Shaddock, J. G. Jr., (1981). The binding of N-hydroxy-2-acetylaminofluorene to DNA and repair of the adducts in primary rat hepatocyte cultures. Carcinogenesis 2, 97-102.

Irving, C. C. (1962). N-hydroxylation of 2-acetylaminofluorene in the rabbit. Cancer Res. 22, 867-873.

Kaderbhai, M. A., Bradshaw, T. K., and Freedman, R. B. (1982). Alterations in the enzyme activity and polypeptide composition of rat hepatic endoplasmic reticulum during acute exposure to 2-acetylaminofluorene. Chem. Biol. Interact. 39, 279-299.

Kiese, M., Renner, G., and Wiedemann, I. (1966). NHydroxylation of 2-aminofluorene in the guinea pig and by guinea pig liver microsomes in vitro. Naunyn Schmiedebergs Arch. Exp. Pathol. Pharmakol. 252, 418-423.

Koch, K., and Leffert, H. L. (1974). Growth control of differentiated fetal rat hepatocytes in primary monolayer culture. VI. Studies with conditioned medium and its functional interactions with serum factors. J. Cell Biol. 62, 780-791.

Koch, K. S., and Leffert, H. L. (1980). Growth control of differentiated adult rat hepatocytes in primary culture. Ann. N. Y. Acad. Sci. 349, 111-127.

Koch, K. S., and Leffert, H. L. (2015). Basic science of liver cancer stem cells and hepatocarcinogenesis. In Principles of Stem Cell Biology and Cancer, Future Applications and Therapeutics (T. Regad, T. J. Sayers, and R. C. Rees, Eds.), pp. 273-304. John Wiley \& Sons, Ltd, Chichester, UK.

Koch, K. S., Moran, T., Shier, W. T., and Leffert, H. L. (2018). Highaffinity low-capacity and low-affinity high-capacity N-acetyl-2-aminofluorene (AAF) macromolecular binding sites are revealed during the growth cycle of adult rat hepatocytes in primary culture. Toxicol Sci. 163, 35-44.

Kosugi, S., Hasebe, M., Tomita, M., and Yanagawa, H. (2009). Systematic identification of cell cycle-dependent yeast nucleocytoplasmic shuttling proteins by prediction of composite motifs. Proc. Natl. Acad. Sci. U.S.A. 106, 10171-10176. http://nls-mapper.iab.keio.ac.jp/cgi-bin/NLS Mapper_form.cgi

Kozlowski, L. P. (2016). IPC - isoelectric point calculator. Biol. Direct 11, 55-31. http://isoelectric.ovh.org/

Kriek, E. (1974). Carcinogenesis by aromatic amines. Biochim. Biophys. Acta 355, 177-203.

Kriek, E. (1992). Fifty years of research on N-acetyl-2-aminofluorene, one of the most versatile compounds in experimental cancer research. J. Cancer Res. Clin. Oncol. 118, 481-489.

Kruijer, W., Skelly, H., Botteri, F., van der Putten, H., Barber, J. R., Verma, I. M., and Leffert, H. L. (1986). Proto-oncogene expression in regenerating liver is simulated in cultures of primary adult rat hepatocytes. J. Biol. Chem. 261, 7929-7933.

Leffert, H. L., and Weinstein, D. B. (1976). Growth control of differentiated fetal rat hepatocytes in primary monolayer culture. IX. Specific inhibition of DNA synthesis initiation by very low density lipoprotein and possible significance to the problem of liver regeneration. J. Cell Biol. 70, 20-32.

Leffert, H. L., and Koch, K. S. (1977). Proliferation of hepatocytes. Ciba Found. Symp. 55, 61-82.

Leffert, H. L., Koch, K. S., Moran, T., and Williams, M. (1979). Liver cells. In Methods in Enzymology (S.P. Colowick, and N.O. Kaplan, Eds.), Vol. 58, pp. 536-544. Academic Press, New York, San Francisco and London.

Leffert, H. L., Koch, K. S., Sell, S., Skelly, H., and Shier, W. T. (1983). Biochemistry and biology of N-acetyl-2-aminofluorene in primary cultures of adult rat hepatocytes. In Application of Biological Markers to Carcinogen Testing (H.A. 
Milman, and S. Sell, Eds.), U S Environmental Protection Agency, Environmental Science Research. Vol. 29, pp. 119-133. Plenum Press, New York.

Leffert, H. L., Moran, T., Boorstein, R., and Koch, K. S. (1977). Procarcinogen activation and hormonal control of cell proliferation in differentiated primary adult rat liver cell cultures. Nature 267, 58-61.

Lotlikar, P. D., and Luha, L. (1971). Acetylation of the carcinogen $\mathrm{N}$-hydroxy-2-acetylaminofluorene by acetyl Coenzyme A to form a reactive ester. Mol. Pharmacol. 7, 381-388.

Luo, C., Krishnasamy, R., Basu, A. K., and Zou, Y. (2000). Recognition and incision of site-specifically modified C8 guanine adducts formed by 2-aminofluorene, $\mathrm{N}$-acetyl-2-aminofluorene and 1-nitropyrene by UvrABC nuclease. Nucleic Acids Res. 28, 3719-3724.

McManus, M. E., Minchin, R. F., Sanderson, N. D., Wirth, P. J., and Thorgeirsson, S. S. (1983). Kinetic evidence for the involvement of multiple forms of human liver cytochrome P-450 in the metabolism of acetylaminofluorene. Carcinogenesis 4, 693-697.

Michalopoulos, G., and Pitot, H. C. (1975). Primary culture of parenchymal liver cells on collagen membranes. Morphological and biochemical observations. Exp. Cell Res. 94, 70-78.

Michalopoulos, G., Sattler, G., Sattler, C., and Pitot, H. C. (1976). Interaction of chemical carcinogens and drug-metabolizing enzymes in primary cultures of hepatic cells from the rat. Am. J. Pathol. 85, 755-772.

Miller, E. C. (1978). Some current perspectives on chemical carcinogenesis in humans and experimental animals: Presidential Address. Cancer Res. 38, 1479-1496.

Miller, J. A., Cramer, J. W., and Miller, E. C. (1960). The N- and ring hydroxylation of 2-acetylaminofluorene during carcinogenesis in the rat. Cancer Res. 20, 950-962.

Miller, E. C., Miller, J. A., and Hartmann, H. A. (1961). N-Hydroxy2-acetylaminofluorene: A metabolite of 2-acetylaminofluorene with increased carcinogenic activity in the rat. Cancer Res. 21, 815-824.

Mishra, L., Mishra, L., Banker, T., Murray, J., Byers, S., Thenappan, A., He, A. R., Shetty, K., Johnson, L., and Reddy, E. P. (2009). Liver stem cells and hepatocellular carcinoma. Hepatology 49, 318-329.

Monteith, D. K., Michalopoulos, G., and Strom, S. C. (1988). Metabolism of acetylaminofluorene in primary cultures of human hepatocytes: Dose-response over a four-log range. Carcinogenesis 9, 1835-1841.

Morris, H. P., Weisburger, E. K., and Weisburger, J. H. (1956). Urinary metabolites of the carcinogen $\mathrm{N}$-2-fluorenylacetamide. J. Natl. Cancer Inst. 17, 345-361.

Nebert, D. W., Nelson, D. R., Coon, M. J., Estabrook, R. W., Feyereisen, R., Fujii-Kuriyama, Y., Gonzalez, F. J., Guengerich, F. P., Gunsalus, I. C., Johnson, E. F., et al. (1991). The P450 superfamily: Update on new sequences, gene mapping, and recommended nomenclature. DNA Cell Biol. 10, 1-14.
Nigg, E. A., Baeuerle, P. A., and Lührmann, R. (1991). Nuclear importexport: In search of signals and mechanisms. Cell 66, 15-22.

Ooi, K., Shiraki, K., Sakurai, Y., Morishita, Y., and Nobori, T. (2005). Clinical significance of abnormal lipoprotein patterns in liver diseases. Int. J. Mol. Med. 15, 655-660.

Ryzewski, C. N., and Malejka-Giganti, D. (1982). Systems for separation of metabolites of the carcinogen, N-2-fluorenylacetamide, by high-performance liquid chromatography. J. Chromatogr. 237, 447-456.

Santostefano, M. J., Richardson, V. M., Walker, N. J., Blanton, J., Lindros, K. O., Lucier, G. W., Alcasey, S. K., and Birnbaum, L. S. (1999). Dose-dependent localization of TCDD in isolated centrilobular and periportal hepatocytes. Toxicol. Sci. 52, 9-19.

Schrenk, D., Gant, T. W., Michalke, A., Orzechowski, A., Silverman, J. A., Battula, N., and Thorgeirsson, S. S. (1994). Metabolic activation of 2-acetylaminofluorene is required for induction of multidrug resistance gene expression in rat liver cells. Carcinogenesis 15, 2541-2546.

Schweikl, H., Taylor, J. A., Kitareewan, S., Linko, P., Nagorney, D., and Goldstein, J. A. (1993). Expression of CYP1A1 and CYP1A2 genes in human liver. Pharmacogenetics 3, 239-249.

Spilman, S. D., and Byard, J. L. (1981). Metabolism of 2-acetylaminofluorene in primary rat hepatocyte cultures. J. Toxicol. Environ. Health 7, 93-106.

Teebor, G. W., and Becker, F. F. (1971). Regression and persistence of hyperplastic hepatic nodules induced by N-2Fluorenylacetamide and their relationship to hepatocarcinogenesis. Cancer Res. 31, 1-3.

Trickett, J. I., Patel, D. D., Knight, B. L., Saggerson, E. D., Gibbons, G. F., and Pease, R. J. (2001). Characterization of the rodent genes for arylacetamide deacetylase, a putative microsomal lipase, and evidence for transcriptional regulation. J. Biol. Chem. 276, 39522-39532.

UniProt Consortium. (2018). UniProtKB - http://www.uniprot.org/.

Weinstein, I. B. (1978). Current concepts on mechanisms of chemical carcinogenesis. Bull. N. Y. Acad. Med. 54, 366-383.

Weisburger, J. H., Grantham, P. H., Vanhorn, E., Steigbigel, N. H., Rall, D. P., and Weisburger, E. K. (1964). Activation and detoxification of N-2-fluorenylacetamide in man. Cancer Res. 24, 475-479.

Weisburger, J. H., and Weisburger, E. K. (1973). Biochemical formation and pharmacological, toxicological, and pathological properties of hydroxylamines and hydroxamic acids. Pharmacol. Rev. 25, 1-66.

Wilson, R. H., DeEds, F., and Cox, A. J. Jr., (1941). The toxicity and carcinogenic activity of 2-acetaminofluorene. Cancer Res. 1, 595-608.

Yang, J. D., and Roberts, L. R. (2010). Hepatocellular carcinoma: A global view. Nat. Reu. Gastroenterol. Hepatol. 7, 448-458.

Zhou, S. F., Wang, B., Yang, L. P., and Liu, J. P. (2010). Structure, function, regulation and polymorphism and the clinical significance of human cytochrome P450 1A2. Drug Metab. Rev. $42,268-354$. 